University of Nebraska - Lincoln

DigitalCommons@University of Nebraska - Lincoln

Faculty Publications in Computer \& Electronics Electrical \& Computer Engineering, Department Engineering (to 2015)

9-2009

\title{
Polarization Diversity for Indoor Wireless Communications
}

Tadeusz Wysocki

University of Nebraska-Lincoln, wysocki@uow.edu.au

Jason Uher

University of Nebraska-Lincoln

Beata J. Wysocki

University of Nebraska-Omaha, bwysocki@mail.unomaha.edu

Follow this and additional works at: https://digitalcommons.unl.edu/computerelectronicfacpub

Part of the Computer Engineering Commons

Wysocki, Tadeusz; Uher, Jason; and Wysocki, Beata J., "Polarization Diversity for Indoor Wireless Communications" (2009). Faculty Publications in Computer \& Electronics Engineering (to 2015). 60. https://digitalcommons.unl.edu/computerelectronicfacpub/60

This Article is brought to you for free and open access by the Electrical \& Computer Engineering, Department of at DigitalCommons@University of Nebraska - Lincoln. It has been accepted for inclusion in Faculty Publications in Computer \& Electronics Engineering (to 2015) by an authorized administrator of DigitalCommons@University of Nebraska - Lincoln. 


\section{Polarization Diversity for Indoor Wireless Communications}

Tadeusz A Wysocki, Jason Uher, Beata J Wysocki, University of Nebraska - Lincoln

As the demand for high wireless data rates in indoor environments grows, we must find new ways to increase the performance of wireless links in muliti-path fading. One common way to do this is to add diversity in the form of spatial or temporal diversity through the application of space-time block codes (STBCs). Recently, a method for combining STBCs with polarization diversity has been presented that allows for modeling the changes in polarization with quaternion numbers, introducing space-timepolarization block codes (STPBCS). This presentation shows some results from an initial investigation into the quality of cross polarized channels as compared to spatially separated channels to determine the feasibility of using STPBCs to enhance wireless data rates. It also presents a comparison of ergodic capacity of cross polarized channels and spatially separated transmits with polarized receive channels to compare the usefulness of hybrid spatial/polarization diversity schemes.

\section{About the speaker:}

Tadeusz A. Wysocki (SMIEEE) received the MEngSc degree with the highest distinction in telecommunications from the Academy of Technology and Agriculture, Bydgoszcz, Poland, in 1981. From then till the end of 1991, he was with the Academy of Technology and Agriculture. In 1984, after three years of research in the area of modulation theory, he received his PhD degree, summa cum laude, from the Warsaw University of Technology. He then continued research into combined modulation and coding and in 1990, he was awarded the DSc degree (Habilitation) in telecommunications engineering from the Warsaw University of Technology. In January 1992, he moved to Australia, where he worked at different Universities and research centers. He spent the whole 1993 at the University of Hagen, Germany, within the framework of Alexander von Humboldt Research Fellowship, and in December 1998, he joined the University of Wollongong as an associate professor. In 2003, he established the Wireless Research Group within the Telecommunications \& Information Technology Research Institute (TITR), which he directed until the end of 2007, when he moved to take up a Professorship of Computer and Electronics Engineering at Peter Kiewit Institute at the University of Nebraska - Lincoln. Dr Wysocki is the author or co-author of seven books, over 200 research publications and nine patents. His areas of research interest include: propagation of microwaves, diversity techniques, digital modulation and coding schemes, space-time signal processing, as well as mobile data protocols including those for ad-hoc networks and nano-networking. 